\title{
Practicum-Based Science Teaching: Building Students' Concept Mastery, Practicum Skills, and Scientific Attitudes
}

\author{
Rohani $^{1}$, Yennie Indriati Widyaningsih ${ }^{2}$, Abdul Hakim ${ }^{3}$ \\ \{rohani.rohani28@gmail.com ${ }^{1}$, yennie_widyaningsih@yahoo.com ${ }^{2}$, \\ ganden.hakim@gmail.com ${ }^{3}$ \} \\ Institut Pendidikan Indonesia, Jl. Terusan Pahlawan No.83, Garut 44151 1,2,3
}

\begin{abstract}
This study was focused on building concept mastery, practicum skills, and scientific attitudes among eight grade students through practicum-based science teaching. This study employed a one-group pretest-posttest pre-experimental study design. Measurements were performed using a concept mastery test, a practicum assessment observation instrument, and a scientific attitude assessment observation instrument. The results of data analysis revealed that students' concept mastery moderately improved by an average $\langle\mathrm{g}\rangle$ of 0.68 , practicum skills improved by $\geq 76 \%$, and scientific attitudes improved by $89.28 \%$. It can be concluded that practicum-based science teaching could help build students' concept mastery, practicum skills, and scientific attitudes.
\end{abstract}

Keywords: concept mastery, practicum skills, scientific attitudes, practicum-based science teaching.

\section{Introduction}

Science education is a product and process. Science products include facts, concepts, principles, theories and laws. While the science process includes ways of obtaining knowledge, developing and applying knowledge that includes how to work, how to think, how to solve problems and how to behave. The ability to apply science concepts in everyday life by Jack Hoolbrok (2009) is called science literacy skills, so it can be said that mastery of concepts and scientific literacy are two things that must be improved.

Wollfold \& Nicolish (2004) said that concepts mastery is the ability of students that not only understand but also can apply the concepts given in solving problems even to understand the new concepts. In the learning process with well-structured activities can results an increase in students' concepts mastery (Yang, R, 2006), and through learning based practicum students can get experiences in which students interact with material to observe and understand natural phenomena (Score, 2008). Through learning based practicum processes can also create and invite students to be active in learning activities (Kobierska et al., 2007).

One aspect that was developed in learning science at school is the attitude aspect. According to Reid Gokhale et al., (2009) attitude is "a positive or negative sentiment or mental state, that is learned and organized through experience on the affective and conative responses of an individual toward some other individual, object, or event". According to Martin, et al. (2005) scientific attitudes include (1) the desire to know and understand, (2) ask everything, (3) collect data and give meaning based on the data, (4) demand verification, (5) 
think logically, and (6) consider ideas. The attitude developed in science is a scientific attitude that is commonly called scientific attitude. Scientific attitude influences students' willingness to participate in scientific activities (Sorge and Hagerty, 2000).

Integrated science learning has a positive effect and an increase in student learning at science lessons (Becker and Park, 2011). Along with Plotrick et al. (2009) 's research stated that integration across disciplines in science could improve the quality of practical activities skills in the laboratory. This science learning based practicum is expected that students can understand the main concepts and be able to connect between concepts in science subjects. Concepts mastery, process skills (practicum) and scientific attitudes of students in integrated science learning is very important

\section{Research Methods}

The purpose of this study was to analyze the increase in concepts mastery, practical skills, and scientific attitudes of students as well as the implementation of learning integrated science through learning based practicum on the theme of human respiration. The research method used was a pre-experimental method with one group pretest and posttest design. Data collection tools were used to measure concepts mastery, practical skills, and scientific attitudes of students were tests of concept mastery skills, observation of student practicum skills assessment, observation of students' scientific attitude assessment, and observation of learning implementation. According to Sugiyono (2012), one group pretest and posttest design is a technique to determine the effects before and after giving treatment. The location of this research was conducted at one of the Junior High Schools in Garut. The subjects of this study were 35 students of eight grade class in the first semester of the 2015/2016.

\subsection{Research Instrument \\ 2.1.1 Concept Mastery Test}

The test instrument used was a written test of an essay. It is based on indicators in Bloom's revised taxonomy C1, C2, C3, and C4, Anderson and Krathwohl (2010).

\subsubsection{Observation Sheet for Practical Skills}

The observation sheet used is a rubric containing aspects and indicators that have been developed from Science Process Skills (KPS), namely skills in aspects and indicators according to Rustaman (2003). There are 1) aspects of planning experiments/research; 2) aspects of using tools and materials; 3) observing/observing aspects; 4) communication aspects. The measurement scale used is the rating scale (Numerical Rating Scale). This scale is used to measure students' practical skills during the learning process.

\subsubsection{Observation Sheet for Scientific Attitude}

The observation sheet used was a rubric containing aspects and indicators of scientific attitudes that have been developed by Dimyati and Mujiono (2006). It includes 1) aspects of accuracy; 2) aspects of honesty; 3) aspects of responsibility; 4) aspects of cooperation.

\subsubsection{Observation Sheet of Learning Implementation}


This observation sheet is used to observe the implementation of learning based practicum on the material of human respiration (the workings of the lungs with simple teaching aids), the frequency of the lungs, the vital capacity of the lungs and the expiration process by the lesson plan implementation.

\subsection{Data Collection and Analysis Techniques}

The data collection techniques in this study can be seen in Table 1 below:

Table 1. Data Collecting Technique

\begin{tabular}{llll}
\hline Data Resource & \multicolumn{1}{c}{ Data } & \multicolumn{1}{c}{$\begin{array}{c}\text { Data collecting } \\
\text { Technique }\end{array}$} & \multicolumn{1}{c}{ Information } \\
\hline Student & $\begin{array}{l}\text { Level of concept } \\
\text { mastery }\end{array}$ & Essay test & $\begin{array}{l}\text { Taken at the beginning and the } \\
\text { end of the learning process }\end{array}$ \\
\hline Student & $\begin{array}{l}\text { Ability of student } \\
\text { practicum skill aspect }\end{array}$ & Rating scale score & $\begin{array}{l}\text { Taken during the learning } \\
\text { process }\end{array}$ \\
\hline Student & $\begin{array}{l}\text { Scientific attitude } \\
\text { aspect }\end{array}$ & Rating scale score & $\begin{array}{l}\text { Taken during the learning } \\
\text { process }\end{array}$ \\
\hline Teacher & $\begin{array}{l}\text { Learning } \\
\text { implementation }\end{array}$ & $\begin{array}{l}\text { Observation sheet of } \\
\text { learning implementation }\end{array}$ & $\begin{array}{l}\text { Taken during the learning } \\
\text { process }\end{array}$ \\
\hline
\end{tabular}

Data Analysis Technique divided into two things, they are :

a. Validation of Test Instruments.

To get description of students' concepts mastery, good tests are needed. Before being used, the test is tested first to find out the validity, the level of difficulty, the difference and reliability.

b. Data Processing Techniques.

Data obtained are quantitative and qualitative data. Data analysis and processing are based on collected data and research questions. Quantitative data was scored concept mastery test, practical skills and scientific attitudes of students. The steps taken in the data processor are as follows 1) Processing data to measure students' concepts mastery through pretest and posttest. 2) Processing data on student practical skills through observation sheets. 3) Processing students' scientific attitude data through an observation sheet. 4) Processing learning implementation observation data through an observation sheet.

\section{Results and Discussion}

\subsection{Improving Student Concepts Mastery}

The results of the study generally indicate an increase in students' concepts mastery. The increase can be seen in the data from the results of pretest, posttest, and $\langle\mathrm{g}\rangle$ students' concepts mastery in Table 2 .

Table 2. Data Analysis Result of Concept Mastery Test 


\begin{tabular}{cccccccc}
\hline Test & Ideal Score & $\begin{array}{c}\text { Highest } \\
\text { Score }\end{array}$ & $\begin{array}{c}\text { Lowest } \\
\text { Score }\end{array}$ & Average & \multicolumn{2}{c}{$\langle\mathrm{g}\rangle$} \\
\cline { 1 - 4 } & 30 & 22 & 11 & 16,8 & & 0,68 & Modest \\
\hline Posttest & 30 & 30 & 20 & 25,8 & & \\
\hline
\end{tabular}

Based on Table 2. above shows that students concepts mastery has an increase after the implementation of learning based practicum. The increase can be seen on the score of students before treatment (pretest) and after treatment (posttest). Furthermore, to see the percentage increase in students' concepts mastery as a whole can be seen through the graph below,

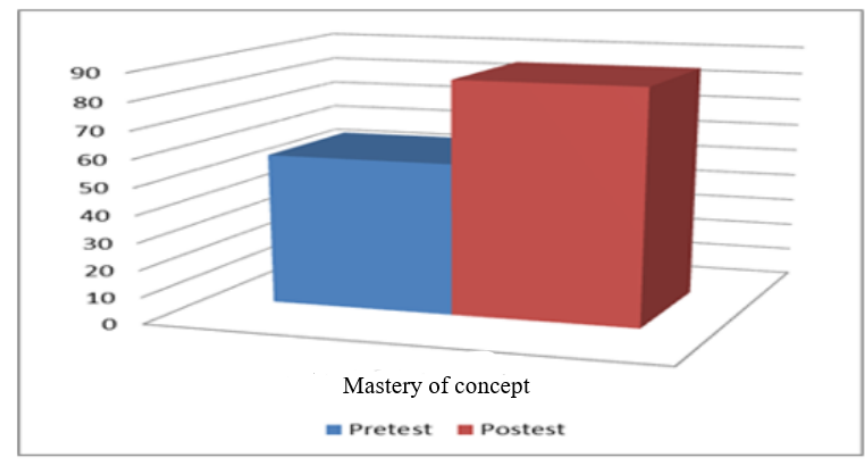

Graph 1. Average Pretest and Posttest Student's Concepts Mastery

This graph shows that after learning based practicum, students concepts mastery has increased in the medium category. It occurs because of students actively and directly to gain knowledge and understanding of the theory in the learning process. This is appropriate with the results of research findings conducted by Trundle and Atwood (2010) that learning through direct observation students can find a concept and understanding students' concepts scientifically.

\subsection{Student Practicum Analysis}

This skills aspect was measured with a scoring sheet as Numerical Rating Scale rubric to observe students' ability to carry out practical activities during the learning process by giving scores based on predetermined criteria in each practicum material (Santyasa, 2006). The research sample was divided into six groups to conducttrial/observation activities. The following is a percentage of each skill aspect in the student practicum process for each group shown in Table 3.

Table 3. Average Percentage of Student's Practicum Aspect

\begin{tabular}{cllcc}
\hline No & \multicolumn{1}{c}{ Skill Aspect } & \multicolumn{1}{c}{ Indicator } & Percentage & Category \\
\hline 01 & Planning trial/research & $\begin{array}{l}\text { Determine what will be } \\
\text { carried out / work step }\end{array}$ & $93,88 \%$ & Good \\
\hline 02 & Using tools and materials & $\begin{array}{l}\text { Knowing how to use tools } \\
\text { and materials }\end{array}$ & $91,04 \%$ & Good \\
\hline 03 & Observation & $\begin{array}{l}\text { Use as many as sense as } \\
\text { possible and collect relevant } \\
\text { facts. }\end{array}$ & 83,74\% & Good \\
\hline
\end{tabular}




\begin{tabular}{lllll}
\hline 04 & Communication & $\begin{array}{l}\text { Arrange and submit report } \\
\text { systematically }\end{array}$ & 84,16\% & Good \\
\hline
\end{tabular}

Table 3. above shows that the overall percentage students' skills aspect in practicum activities is in good category (Arikunto 2010). According to Morrison research (2012), practicum skills use the senses based on working procedures in practical activities, to obtain information from objects or a natural phenomenon. The results of the research by Engler and Russell (2000) are also stated that students who conduct learning through practical activities increased their skills in practicum. Research conducted by Spiro and Knisely (2008) is also said that learning based practicum could develop practical skills and apply concepts.

\subsection{Analysis of Aspects of Students' Scientific Attitudes.}

The aspect of students 'scientific attitudes is measured using the Rating Scale assessment sheet to observe students' scientific attitudes during the learning process. The following is the average score of each aspect of students' scientific attitudes during the learning activities process shown in Table 4.

Table 4. Average Percentage of Student's Scientific Attitudes Score

\begin{tabular}{|c|c|c|c|c|}
\hline No & Attitude Aspects & Attitudes Indicators & First meeting & Second meeting \\
\hline 01 & Accuracy & $\begin{array}{l}\text { Doing trial step correctly/ students can } \\
\text { answer LKS correctly }\end{array}$ & 59,28 & 82,14 \\
\hline 02 & Honestly & $\begin{array}{l}\text { Do not manipulate data and do not copy } \\
\text { worksheet result of another group. }\end{array}$ & 55,71 & 87,14 \\
\hline 03 & Responsible & $\begin{array}{l}\text { Students attitude in reviewing } \\
\text { information and applying in experiments } \\
\text { and discussion procedure }\end{array}$ & 61,42 & 90 \\
\hline 04 & $\begin{array}{c}\text { Group } \\
\text { Collaboration }\end{array}$ & Students attitude in collaborating group & 62,85 & 97,85 \\
\hline & & Total & 239,26 & 357,13 \\
\hline & & Average $(\%)$ & 59,81 & 89,28 \\
\hline & & Category & Medium & Very high \\
\hline
\end{tabular}

Table 4. above shows that the results of observations students scientific attitudes during the learning process have increased from the first meeting to the second meeting on each indicator. In the first meeting, the percentage was $59.8 \%$ with the medium category, and in the second meeting, the percentage was $89.28 \%$ with a very high category (Arikunto, 2010). The same with the research conducted by Kobierska, Fiertak and Grodzinska (2007) that learning based practicum can create conditions where students become able to collaborate and be more active in the process of learning activities. This is by the statement of the Ministry of Education (2006) that practical activities carried out by students during the learning process in the classroom can develop students' scientific attitudes.

\subsection{Analysis of Implementation Learning Based Practicum}


Based on observers' observations on the activities of teachers in the learning process, they have carried out the learning process and implementation of learning based practicum on the theme of human respiration. It shows that the implementation of learning has been going well and very high.

\section{Conclusion}

Based on data processing, data analysis and discussion, we can conclude that; in general, Student's concepts mastery has increased through Integrated Science Learning Based Practicum with an average score of $<\mathrm{g}>0,68$ (medium category). Student's practicum skill through integrated science learning based practicum during the learning process take place has percentage $\geq 76 \%$ on all indicators of practicum skill in the good category. The scientific attitude of the student's through integrated science learning based practicum during the learning process is increased with an average percentage of $89,28 \%$ (very high category). Integrated science learning based practicum has done $100 \%$ according to the lesson plan (RPP). The teacher has carried out the learning process and implementation of integrated science learning based practicum on the theme of "Human Respiration", and it was run very well.

\section{References}

[1] Holbrook, J. (2009). A Source Book for Teacher of Science Subjects. Science Education International. $4(3), 63-76$

[2] Woolfolk, Anita \& Lorrance MccuneNicolas. (2004). Mengembangkan Kepribadian dan Kecerdasan Anak-Anak. Jakarta; Inisiasi Press.

[3] Yang, R. (2006). The Relationship Between Learning Styles and L2 Learning. Sino-Us English Teaching.3, (9), 25-28

[4] Score. (2008). Practical Work in Science: A Report and Proposal for A Strategic Framework. International Journal of Science Education. 30. (14), 20-27

[5] Kobierska, H., Fiertak, M. T \& Grodzinska, M. J. (2007). “ Attitude to Environmental Education in Poland". Journal of Biology Education. 42(1), 12-18

[6] Gokhale A., Brauchle P., and Machina, K. (2009). Development and validation of a scale to measure attitudes toward science and technology. Journal of College Science Teaching, 38 (5), 66-74

[7] Martin R., Sexton, C., Franklin, T. \& Gerlovich, J. (2005). Teaching science for all children, inquiry methods for constructing understanding. Journal of Science Teacher Education. 11 (1), 1-25

[8] Sorge, C., Horton, N. \& Hagerty, J. J. (2015). “ Fun Is Not Enough: Attitudes of Hispanic Middle School Students Toward Science and Scientists" Hispanic Journal of Behavioral of Science.22 (3), 332345 
[9] Becker, K. H. \& Park, K. (2011). Integrative Approaches Amon Science, Technology, Engineering, and Mathematics (STEM). The subject on Students Learning: A Meta-Analysis. Journal of STEM Education: Innovations and Research. 12 (5), 23-37

[10] Plotrick, R. E., \& Fan, Q. (2009). An Integrated Earth Science, Astronomy, and Physics Course for Elementary Education Majors. Journal of Geoscience Education, 57 (2), 152-158

[11] Sugiyono. (2012). Metodologi Penelitian Kuantitatif Kualitatif dan R\&D. Alfabetha: Bandung

[12] Anderson, L.W, \& Krathwohl, D.R. (2010). Kerangka Landasan Untuk Pembelajaran, Pengajaran, dan Assesmen ( Revisi Taksonomi Pendidikan Bloom). Yogyakarta: Pustaka Pelajar.

[13] Rustaman, N. Y. (2003). Asessmen Dalam Pembelajaran Sains. Bandung: Universitas Pendidikan Indonesia

[14] Dimyati \& Mujiono (2006). Belajar dan Pembelajaran. Rineka Cipta: Jakarta

[15] Trundle, K. C, \& Atwood, R. K, (2010). The Effect of Guided Inquiry-Based Instruction on Middle School Students. " under Standing Lunar Concept" Research Science Education. 451-478

[16] Santyasa, I W. 2006. Asesmen Proses dan Produk Belajar. Makalah. Disajikan Dalam Pembahasan Model-Model Asesmen Bersama Guru-Guru SMA Negeri 1 Singaraja, Tanggal 22 Desember 2006, di Singaraja.

[17] Arikunto, S. (2010). Prosedur Penelitian: Suatu Pendekatan Praktik Edisi Revisi VI. Jakarta: PT. Rineka Cipta

[18] Morrison, K. (2012). Integrate Science and Arts Process Skills in The Early Childhood. 40 (1), 5360

[19] Engler, J \& Russel, J. (2000). Small Scale chemistry. Michigan Departement of Environment Quality Journal Spring 21 (1), 28-35

[20] Spiro, M. D. \& Knisely, K I. (2008). Alternation of Generation and Experimental Design : A Guided The Nature of The Hell Developmental Muntant of Cevatopterisrichaardii. CBE-LIFE Sciences Education. 7 (1), 82-88

[21] Depdiknas. (2006). Badan Nasional Standar Pendidikan. Jakarta: Pusat Penilaian Pendidikan Departemen Pendidikan Nasional. 
